\title{
Teachers' Perception of the Influence of Teacher's Experience on Pupil's Ability to Read and Write in Public Pre- Schools in Eldoret East Sub-County
}

Chebet Everlyne, Esther Bittok

To Link this Article: http://dx.doi.org/10.6007/IJARBSS/v11-i1/8461

DOI:10.6007/IJARBSS/v11-i1/8461

Received: 02 November 2020, Revised: 29 November 2020, Accepted: 17 December 2020

Published Online: 14 January 2021

In-Text Citation: (Everlyne \& Bittok, 2021)

To Cite this Article: Everlyne, C., \& Bittok, E. (2021). Teachers' Perception of the Influence of Teacher's Experience on Pupil's Ability to Read and Write in Public Pre- Schools in Eldoret East Sub-County. International Journal of Academic Research in Business and Social Sciences, 11(1), 160-179.

Copyright: (c) 2021 The Author(s)

Published by Human Resource Management Academic Research Society (www.hrmars.com)

This article is published under the Creative Commons Attribution (CC BY 4.0) license. Anyone may reproduce, distribute, translate and create derivative works of this article (for both commercial and non-commercial purposes), subject to full attribution to the original publication and authors. The full terms of this license may be seen at: http://creativecommons.org/licences/by/4.0/legalcode

Vol. 11, No. 1, 2021, Pg. 160 - 179

Full Terms \& Conditions of access and use can be found at http://hrmars.com/index.php/pages/detail/publication-ethics 


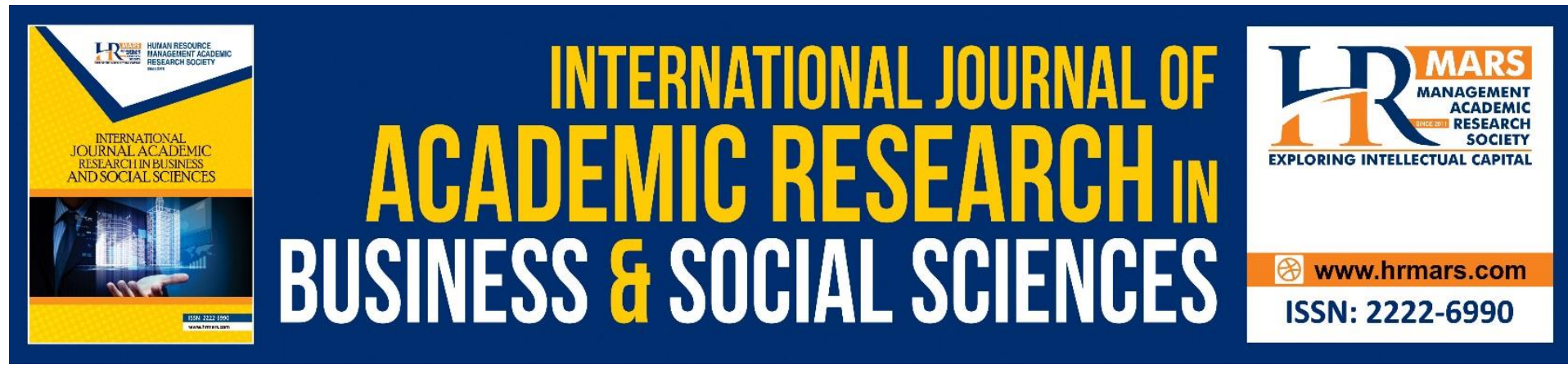

\title{
Teachers' Perception of the Influence of Teacher's Experience on Pupil's Ability to Read and Write in Public Pre- Schools in Eldoret East Sub-County
}

\author{
Chebet Everlyne, DR. Esther Bittok \\ Kisii University, Kenya
}

\begin{abstract}
Despite some significant gains in learner enrolment and community initiatives in Eldoret East Sub-County, there is a wide variation in the level of acquisition of literacy and numeracy skills in public pre-schools. The study sought to determine teachers' perception of the influence of teachers' experience on pupil's ability to read and write in public pre-schools in Eldoret East Sub-County. The study was guided by the Systems Theory, which was advanced by Senge. The study used a descriptive survey research design. This study was conducted in the Eldoret East Sub-County, Uasin-Gishu County, Kenya. The study population was 84 head-teachers, and all the 252 teachers spread in 84 pre-schools in the Sub-County. A stratified random sample of 8 urban pre-schools and 20 rural public pre-schools participated in the study. Respondents in the study were all the selected schools' head-teachers and a stratified random sample of 84 pre-school teachers. A validated questionnaire was used to collect data to ensure the reliability of the questionnaire. A pilot study was conducted. Data were analyzed using descriptive statistical techniques which include percentages and means. Data were presented in charts and frequency tables. This study was done with an appropriate computer programme (statistical package for social sciences - SPSS). The results will be used to improve the effectiveness of pre-school education. The findings will also be used to address any existing challenges that impact the quality of pre-school education. The findings may also be a source of valuable information for further research in areas related to the study.
\end{abstract}

Keywords: Teachers, Perception, Experience, Pupils, Read, Writes

\section{Introduction}

Reading and writing are two of the most important milestones that occur in a child's life. Reading and writing are important not only because they enable the child to enter the world of academia but also because they allow them to communicate with other people; become more sociable; achieve a more interactive lifestyle. Children who possess these skills as they transit to primary school have a firm foundation for future learning. The ability to read is important if one is to succeed in school. This is because the comprehension of everything learnt in school depends on the learner's good reading skills. According to (Tella, 2013), if children do not learn to read, understand, write and use language to communicate their ideas 
and perspectives, their favourable conditions for a fulfilling and rewarding life are seriously compromised.

Researchers have found that children gain the skills necessary to read and write during early childhood (Chacón, 2005). Learning to read and write at a high level of proficiency is a lifelong process; however, it is well established that the early childhood years serve as an important foundation for subsequent literacy development (Hoffman, 2000). The degree to which children acquire requisite literacy skills is a strong predictor of future academic success and has long-term social and economic implications for families and societies (Han, 2009). Early Childhood Development Education (pre-schools) is a critical stage that determines the future of a child. Brain research has been cited for the importance of young children's success to quality care and education from the earliest years in the life (KIE, 2000). This overwhelming evidence of pre-schools' importance has prompted many countries to exhibit clear awareness of the need to embrace pre-schools within Government policy and legislative framework (Kabiru, Njenga, 2007). Despite the global campaigns on Education For All (EFA) and related declaration of children's rights, pre-schools programmes are still poorly managed (UNESCO, 2004). Many stakeholders are still ignorant about pre-schools issues, and therefore many preschools programmes have no policy direction making their efficiency wanting.

The quality of teaching and learning is by far the most salient influence on students' cognitive, affective, and behavioural outcomes regardless of their gender or backgrounds. Factors like teacher experience need to be analysed to establish the role they play in determining school effectiveness. This study hopes to fill this gap by analysing public pre-school teachers in Eldoret East sub-county on whether these factors have any role in the effectiveness of public ECDE education. In Kenya, education is a fundamental human right. Education is a very important sector because it gives a child a fundamental right, and therefore it must be provided to all children irrespective of race, sex or colour. There should be equitable distribution of the national cake and the promotion as well as the preservation of the cultural heritage of the Kenyan people (Kabiru, Njengam \& Swadener, 2003). Therefore, education and training seek to offer equal opportunities to all learners. In Kenya, the formulation and implementation of ECDE policy have not been an easy task since pre-independence. This probably explains why the idea of Kenya becoming highly industrialized had shifting of goals for its target achievement. The brains to have relied upon encounter unrealistic system of education. ECD in Kenya should seek to develop the whole child. The growth and development processing should include physical, mental, social-emotional, moral and spiritual and aesthetic dimensions. ECD programmes in Kenya should reach young children wherever they are, may it be at home, ECDE centres or any other institutions providing care for children. Teachers and caregivers who care for children should have sound knowledge of how children grow, develop and learn to be able to provide for them.

\section{Statement of the Problem}

The Kenyan Constitution provides that every child has a right to free and compulsory basic education inclusive of ECDE, which entails quality services and access to educational institutions and facilities for all persons, including those with disabilities. Similarly, the Kenya Vision 2030 also recognizes that education and training of all Kenyans are fundamental to the success of the vision. Early Childhood Development Education is a critical stage that determines the future of a child. ECDE being the first formal agent of socialization calls all stakeholders' attention to critically address the challenges related to issues of access, equity, quality and relevance of ECDE programmes. In Kenya, ECDE concerns the holistic 
development of children between 3 and 5 years old. Pre-school effectiveness primarily focuses on measuring a school's quality in terms of learners' academic achievement progress in reading and writing. The Ministry of Education reports in Eldoret East Sub-County indicate that private pre-schools excel in reading and writing when children transit to primary schools. Many school management committees use various strategies to ensure learners can read and write by the time they transit to primary school. Some add extra hours to learning time, others buy a lot of teaching and learning materials, yet others employ teachers with certain experience to achieve this end. However, there is scanty literature on factors that contribute to poor performance in public pre-schools. Therefore, this study sought to establish the factors perceived to contribute to the ability of pupils to read and write in public pre-schools by the time they exit pre-school.

\section{Purpose of the Study}

The study was purposed to determine teachers' perception of the influence of teachers' experience on pupil's ability to read and write in public pre-schools in Eldoret East SubCounty.

\section{Research Hypothesis}

i. What is the teacher's perception of the influence of teachers' experience on pupils' ability to read write in public pre-schools in Eldoret East Sub-County?

\section{Empirical Review}

The literature reviewed examines the studies on the influence of teachers' experience.

\section{Influence of Teachers' Experience on Pupils' Acquisition of Reading and Writing Skills}

The curriculum at the pre-school level is broad, and the range of subjects offered is quite wide. It focuses on: language, mathematics, social studies, religious, indoor and outdoor activities and science and environmental activities. Beginning reading is an essential part of the pre-school classroom as this is a prime period in the child's development to build the foundation for reading. Learning to read is therefore an important educational goal which ECDE teachers should endeavor to achieve among their learners in order for a school to be said to be effective. It is for this reason therefore that head teachers of pre-schools need to recruit staff that have certain specific qualities to facilitate learning among which is teacher experience.

According to Angrist and Lavy (2001), there is positive correlation between years of teaching experience and level of qualification, and higher student achievement. Teachers with more than five years in the classroom seem to be the most effective. Conversely, inexperience is shown to have a strong negative effect on student performance. They further reported that studies have found that the students taught by certified teachers scored better. However these researches were conducted in western world and focused on classroom teachers. This current research will focus on school heads because according to (Card \& Krueger, 1996) 'effective schools' are characterized by outstanding educational leadership, particularly as exercised by the school heads and directed at establishing agreed goals, increasing competence and involvement of staff and at clarifying roles and expectations. Moreover, this study focused on ECDE education with special emphasis on rural and urban schools.

According Schleicher (2012), heads of schools who attend more training courses and have longer teaching experience prior to be becoming principals, tend to influence higher 
academic standards. According to UNICEF (2001), a teacher is expected to be experienced when he/she has, at least part of the time seen how children learn, how teaching is done and even how to handle parents and pupil issues. They are expected to have a strong understanding of school development planning, information which is gained either through apprenticeship or attending training on it. Thorpe recommends that for teachers to develop viable curriculum, resource and manpower planning, they need to be in a position to determine priorities and to set realistic targets. An effective teacher needs also to be knowledgeable about the principles of management skills in terms of competencies like professional leadership, sharing vision, structuring working environment, time management and linking the school to the community.

At an ECDE centre, teachers are expected to have specific skills and experiences which may not be applicable to other learning levels. They need to be highly motivated and enthusiastic, have passion for early childhood education, friendly, approachable, and have affection for details and willingness to adapt to children's needs (Hanushek \& Luque, 2003). This ensures that the pre-school provide quality childcare, he/she engages well will children and parents, ensures that learning programs meet the needs of the children and that teachers continually acquire requisite skills and knowledge through mentoring, training and professional development.

The present situation in Eldoret East sub county begs for answers as many public pre-schools post poor results in reading and writing at top class, an indication that they are not effective even though parents and proprietors have invested much materially in them. The Headteacher has the task to realize the goal or provision of quality education to all. They should therefore acquire the requisite skills to enable them exploit their potential to the fullest. They should posses effective audit systems which they use to monitor learner's ability to read and write. This according to Kenya National Examination Council (KNEC) (2010) will bring about quality in service delivery in the school system.

KNEC further explains that a Headteacher should be a visionary leader, curriculum specialist, disciplinarians, senior manager, community representative and a classroom teacher. They are expected to transform the poorest schools to be the best and maintain performance in the best schools. School heads need to possess instructional, participative, transformational, and strategic leadership. They should have passion to explore good leadership traits to make a difference in the learners' ability to read and write the pre-school level. They should put in place the structures, system and cultures that will maintain a school's success far into the future. It is that opportunity which many heads in the education secure may lack (KNEC, 2010).

By ensuring that quality work is done effectively, the Headteacher should sensitize parents to ensure that their children should have adequate time for homework. He should also establish child-friendly school home work policy, be skillful in relationship building that is to demonstrate ability to communicate and build relationships with new and old teachers so as to build their focus and confidence in what they can and should accomplish as a result of enhancing learners' ability to read and write at the pre-school level. Also to ensure that there is encouragement of mixed gender team-teaching so as to address issues of varied performance in both literacy and numeracy.

The headteacher need to have proper credential and knowledge in order to professionally run a pre-school. According to Nacino (1982), they should possess leadership qualities that contribute to smooth school and classroom functioning. According to KNEC (2010), they should acquire the requisite skills to ensure they put in place effective systems to monitor 
learners' ability to read and write. To achieve this, it is important for a teacher to know about official curriculum and the nature and quality of the work done in the school. They need to have knowledge and skills on children learning, teaching methodology and how to consult with community and other variety of people. This will assist the teacher to adjust to good planning for a full and balanced curriculum which ensures the school becomes effective. Teachers needs to understand the requirement for proper curriculum implementation in areas like punctuality of teachers and pupils, interaction among teachers, cleanliness of school compound and discipline of teachers and pupils. Moreover, they need to have understanding of how to put a strong foundation for reading and writing in ECDE level through encouraging staff to embrace key practices necessary for phonological awareness like using poems, alliteration, rhymes and focus on individual children.

According to UNICEF (2010), a head teacher should encourage staff to use peer teaching in reading which research indicate to provide extra reading for weaker children in the class. They should also encourage teachers to work with slow learners in a quiet, friendly and supportive way. Head teachers should encourage teachers to work patiently with pre-school children and endeavor to be learner centre at all times. These study investigated the influence of the teachers' experiences on pupils' ability to read and write in public pre-schools in Eldoret East Sub-County. It sought to find out the perceptions of teachers' on the ability to adopt to the needs of a situation and to change tactics as a situation demands, ability to set clear expectations and parameters and hold others accountable for performance and finally the ability to support children in their learning and to help them become confident and independent learners

\section{Theoretical Framework}

The study will be guided by the Systems Theory which was advanced by Senge (1990). In this theory, a system is defined as a complex of factors interacting according to an over-all plan for a common purpose. According to this theory, organizations are systems with the following features:

(i) They are goal oriented

(ii) Systems are engaged in processing or transformation of inputs into outputs.

(iii) Systems consist of sub-systems which are interdependent, and they coexist.

(iv) Systems are open and dynamic. They have continuous interaction with the environment.

They are sensitive to the environment when it comes to government policies, competition in the market and changes in peoples' tastes. As open systems, organizations are engaged in an exchange relationship with the environment in the form of inputs and outputs. Operations are performed upon inputs combined with managerial processes, produce desirable outputs which are distributed back to the environment. There is a feedback loop that enables the system to make appropriate modifications (changes) to its sub-systems in the light of the changing environment. If the environment is happy with the output, activity continues, but if not, changes are initiated until desirable relationship is established.

The system with its sub-systems constantly adjusts to achieve equilibrium internally and with its environment: open systems readily respond to the changes in order to achieve organizational goals. System' thinking is essential for the development of effective organizations. Changes in any part of an organization's activities affect all other parts.

The constantly changing environmental influences affect the operations of an educational organization and to improve school's performance and management, it is necessary to 
consider how they achieve an internal and external balance and how they are able to adapt to changes in the environment and to demands placed upon them. System theory emphasizes the dependency relationship of the educational organization and the surrounding environment. When needs of the environment shift, the output of the educational organizations (and therefore of the teaching-learning process) must also change if the school is to be an engine of development rather than a contributor to the problems of the society. From the foregoing theoretical exposition, it emerges that schools are open and dynamic systems which must keep on adjusting their management and operations through in-built mechanisms so as to achieve their goals. This study considers the Public ECDE centres as open organisations which should embrace the systems approach in their management and operational practices so as to achieve their goals.

Nasibi (2003) describes a process in a system as the procedures that inputs (teachers, learners, materials) goes through before it comes out as finished product. I the case of the current study, processes to be considered are the activities that pre-schools go through as they work towards effectiveness which in the case of this study is measured by the ability to read and write (output). Wango (2009) posits that for a school to perform well, the process of teaching and learning, school development planning and budgeting need to be well coordinate

The pre-school education will be taken to be a system as different elements are supposed to interact well in order to achieve positive results. The selected factor to be studied was head teachers experience. According to Nasibi (2003) elements of a system must work harmoniously otherwise the goals will not be realized. The selected factors which make part of the elements of education systems were studied with a view to determining the role the pre-school teachers' perception on pupils' ability to read and write. 


\section{Conceptual Framework}

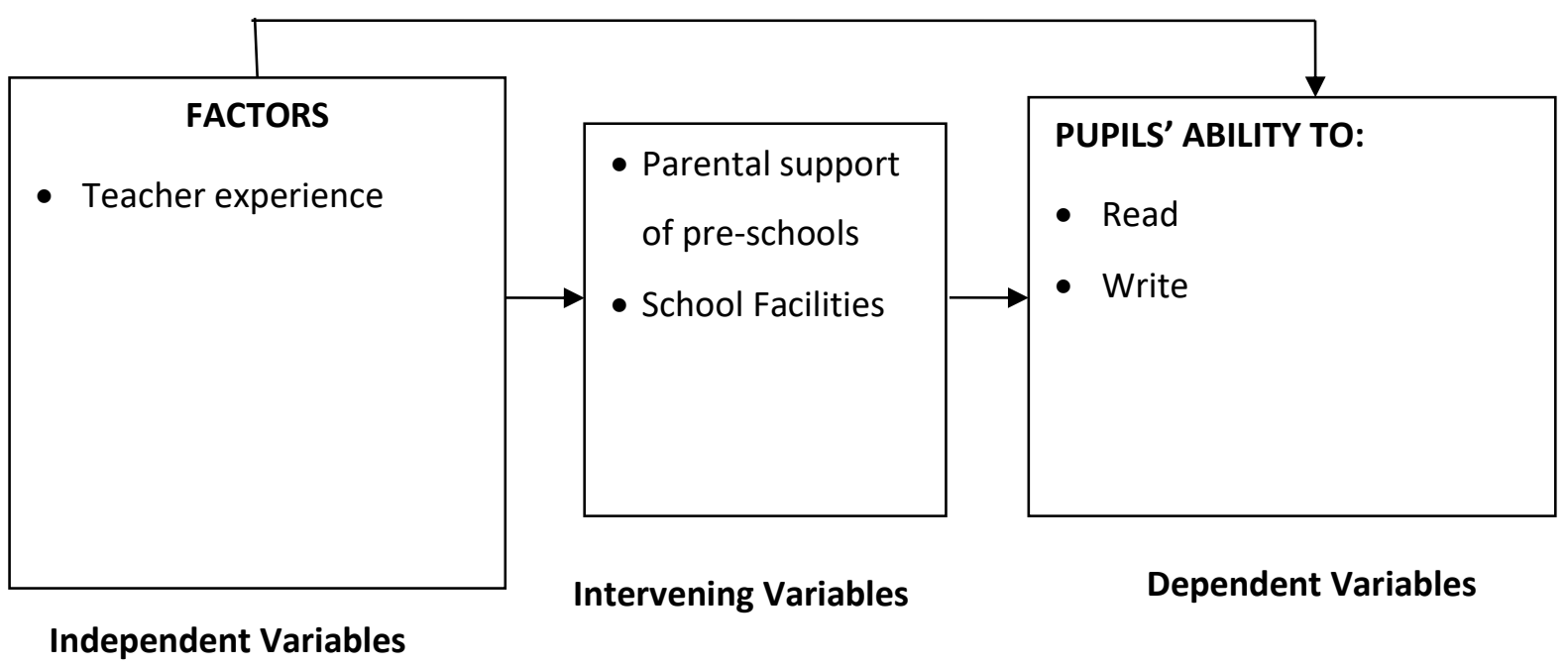

Figure 1 Conceptual Framework

In this conceptual framework, it is conceptualized that teachers' experience influences pupils' ability to read and write. The teachers' experience may be effective if there is parental support. Therefore, the intervening variables will be useful if integrated into the study to minimize its effects.

\section{Research Methodology \\ Research Design}

Research design is defined as a plan, structure or strategy of investigation so conceived so as to obtain answers to research questions or problems (Orodho, 2005). This study used descriptive Survey research design. This design gathers data at a particular point in time with the intention of describing the nature of the existing conditions, identifying the standards against which existing conditions can be compared and determining the relationship that exists between specific events (Orodho, 2005). Descriptive survey research design is suitable in this study since the population studied was large to be observed directly and the information to be obtained is descriptive in nature.

\section{The Study Area}

This study was conducted in the Eldoret East Sub-County of Uasin-Gishu County, Kenya. The Sub-County headquarters is in Eldoret. All the pre-schools in the district were considered for this study. The Sub-County borders Eldoret West Sub-County to the West, Wareng SubCounty to the south, Keiyo Sub-County to the East and Marakwet as well as Trans Nzoia East Sub-County to the North. Its economic activities include: trade, industry and transport, which happen to have an agricultural bias due to the rich agricultural potential of the district. Eldoret East Sub-County has its inhabitants comprising various ethnic groups that make up the country's population. The Sub-County was used for the study because there has been mushrooming of public pre-schools. It therefore gave a wide and varied view of the problem under study. However, it must be observed that the choice of the area does not render other parts of the country less significant. 


\section{Population of the Study}

The study targets all the 84 public pre-schools in the district. All the 252 teachers in the district were targeted. This population was involved in the study because it is directly involved in the teaching and learning process and also in the management of learning institutions. Apart from that, this population directly influences the ability of learners to read and write. The target population is as shown in Table 1.

\section{Table 1: Target populations}

\begin{tabular}{lll}
\hline & Target population & \\
\cline { 2 - 3 } Category of Respondents & Teachers & Headteachers \\
Rural & 180 & 60 \\
Urban & 72 & 24 \\
\hline Total & 252 & 84 \\
\hline
\end{tabular}

Source: DICECE Report, 2012

\section{Sample Size and Sampling Procedures}

Sampling is the process of selecting a sub-set of cases in order to draw conclusions about the entire set. Any statements made about the sample should be true for the entire population. As noted by Cohen \& Manion (2003), factors such as expense, time and accessibility frequently prevent researchers from gaining information from the whole population. Therefore there is need to obtain data from a smaller group or subset of the total population in such a way that the knowledge gained is representative of the total population under study. For the purpose of getting a representative sample, the researcher stratified the schools into rural and urban school. A stratified random sample is a useful blend of randomization and categorization thereby enabling both a quantitative and qualitative process of research to be undertaken (Cohen \& Manion, 2003). The advantage in stratified random sampling is that it ensures inclusion, in the sample of subgroups, which otherwise would be omitted entirely by other sampling methods because of their small numbers in the population.

Proportionate simple random sampling was used to obtain 8 schools from urban areas and 20 schools from rural areas as supported by sample $30 \%$ determination by Orodho (2003) sample. A sample of $8(30 \%)$ urban pre-schools and $20(30 \%)$ rural public pre-schools was selected through proportionate and stratified random sampling to participate in this study. Simple random sampling was used to select teachers to participate in this study in case of doubled stream school and purposive sampling was used to select teachers in single stream schools. Therefore the numbers of teachers selected were 84 teachers. All the 28 head teachers were purposively sampled to participate in the study. The total sample size was 112 respondents. The sample size is as shown in Table 2.

Table 2: Sampling Frame

\begin{tabular}{llll}
\hline Category of Respondents & \multicolumn{2}{l}{ Sample size } & Total \\
\cline { 2 - 3 } & Urban & Rural & \\
Headteachers & 8 & 20 & 28 \\
Teachers & 24 & 60 & 84 \\
\hline Total & 32 & 80 & 112 \\
\hline
\end{tabular}

\section{Instrumentation}

The study used two questionnaire schedules to collect data relevant to the study. 


\section{Questionnaire}

Questionnaire was used in this study for the collection of data. This is because questionnaires provide high accuracy, generalisability and explanatory power, with low cost, rapid speed and maximum management demands and administrative convenience. Secondly, the questionnaires collect views from a large number of respondents within a short time. The questionnaires made it possible to obtain a wide variety of responses and to draw more reliable conclusions from the responses of teachers. Since it is a standard research instrument, it allows for uniformity in the manner in which questions are asked and makes it possible to be compared across respondents (Cohen \& Manion, 2003).

Questions have therefore been developed based on a review of literature designed to explore the main issue cited in the specific purpose of this study. To solicit for the required responses, multiple choice and likert scale type question items were developed. The questionnaire consisted of five sections. Section A deals with the demographic description of the participants. Section B deals with questions related to Head teachers' teaching experience on pupils ability read and write this section helped in achieving objective one of the study.

\section{Data Analysis}

According to Mugenda and Mugenda (1999) analysis of survey data includes; seeing the completeness and the correctness of the data before coding, tabulating responses, translating responses into specific categories, recording them appropriately and computing them using appropriate statistical ways. In this study, descriptive statistical techniques were used in analyzing data. Descriptive statistics according to Mugenda and Mugenda (1999) includes the statistical procedures that produce indices that summarize data and describes the sample. The descriptive statistical techniques include the frequencies, percentages and means. The data obtained from the questionnaire was coded and analyzed using the Statistical Package for Social Sciences (SPSS).

\section{Results and Discussions \\ Demographic Characteristics of the Respondents}

Key teachers and head teachers who are critical in determining the pre-school teachers' perceptions on the influence of selected teacher and school characteristics on pupils' ability to read and write in public pre-schools in Eldoret East sub county, Kenya, informed the study. A total of 80 teachers duly completed and returned the questionnaires while 24 head teachers filled theirs. The demographic information of the respondents included teachers' age, gender, level of education and their teaching experience.

\section{Gender of Respondents}

The participants were asked to indicate their gender in the questionnaire. The results are presented in Table 3.

Table 3: Gender of respondents

\begin{tabular}{lll}
\hline Gender & Frequency & Percentage \\
\hline Female & 69 & 86.25 \\
Male & 11 & 13.75 \\
\hline Total & 80 & 100.00 \\
\hline
\end{tabular}

Table 4.1 shows that $86.25 \%$ of the pre-school teachers were female teachers while $13.75 \%$ of the teachers were male teachers. It emerged from the study findings that majority $(86.25 \%)$ 
of the pre-school in Eldoret East teachers were female teachers. This imbalance could be attributed to many reasons. First is the low remuneration package coupled with no job security making many male teachers not to offer their services at ECDE level. This may be attributed to the reluctance of the male teachers to take up pre-school teaching job which may seem to them to be feminine. This confirms earlier researches done which revealed that most of the pre-school teachers or otherwise called caretakers were mostly women because they could nurture children and give them love, attention, care and other requirements Rotumoi \& Too (2012). From time immemorial, early childhood workers have been women and the trend has not changed. Mothers as first educators identify, recognize and respond to the children's needs with more ease than men. Further this could be attributed to the fact that women are nurturers and the people who are best suited for raising young children (Berk, 2002). According to the ECDE policy Framework (2006), there is no clear policy on teachers' gender however it stipulates that there should be sufficient skilled manpower especially on issues related to young children. The results were further presented in figure 2 .

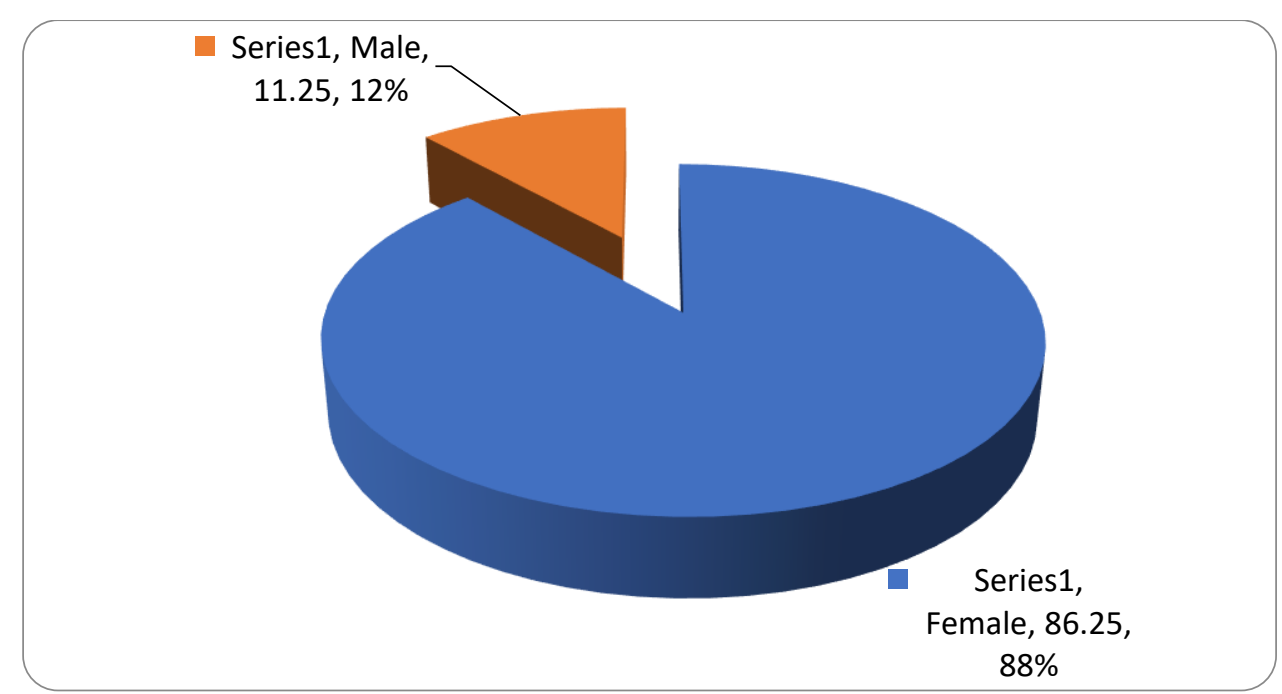

Figure 2: Gender of Respondents

\section{Age Bracket of Respondents}

The respondents were grouped according to the ages and the results are presented in Table 2 . 
Table 4: Age Bracket of respondents

$\mathbf{N}=84$

\begin{tabular}{lll}
\hline Age Bracket & Frequency & Percentage \\
\hline $20-30$ years & 46 & 57.5 \\
$31-40$ years & 21 & 26.25 \\
$41-50$ years & 10 & 12.5 \\
Over 50 years & 3 & 3.75 \\
\hline Total & 80 & 100.00 \\
\hline
\end{tabular}

Table 4 shows that $57.5 \%$ pre-school teachers were aged $20-30$ years, $26.25 \%$ were aged 31 40 years, $12.5 \%$ were aged $41-50$ years while $3.75 \%$ were aged over 50 years. It emerged that majority of the pre-school teachers in the District were aged $20-30$ years. This supports the findings of Githinji (2008) who found out that majority of the pre-school teachers in Kiambu District were aged $21-25$ years. The age of any task force in the society is very important. This shows the strength and weaknesses of the human resources which is a measure in performance of providing the required services needed. Therefore the respondents' analysis revealed that majority of the ECDE public pre-school teachers in Eldoret East were in the age bracket of 20-30 years. This shows that mature and middle age which teachers tend to use a variety of teaching methods for the learners to read and write. These findings are consistent with Demir, C. E. (2009). who asserted that as the teachers grow old, they tend to adopt a discover methods of teaching and handling learners in all levels of learning. Githinji (2008) who suggested that the age of a teachers' determines the types of teaching methods to be used also supports this. The study findings could further imply that the youthful teachers were able to assist learners to read and write but not to the expected standards because majority may lack patience and mostly busy with many activities unlike elderly teachers who focuses at their teaching tasks.

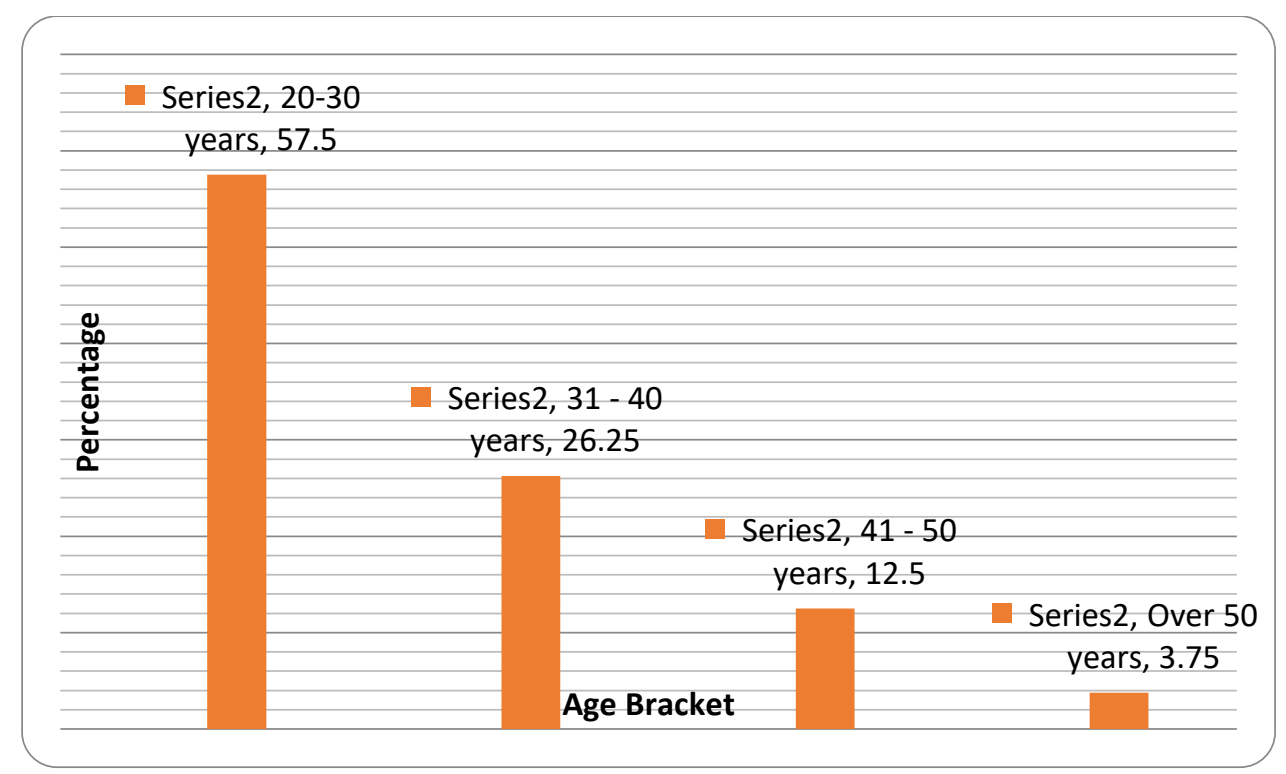

Figure 3: Age Bracket

\section{Level of Education}

The participants were asked to indicate their level of education in the questionnaire. The results are presented in Figure 3. The Figure shows that more than half at $52.5 \%$ of the 
teachers were certificate holders, $31.2 \%$ teachers were diploma holders, $12.5 \%$ teachers were untrained teachers while $3.8 \%$ teachers were having first degree. The study findings showed that majority (87.5\%) teachers had certificate, diploma or first degree an indication that they were in a position to influence positively pupils' ability to read and write in pre-schools and further makes them able to provide a higher quality staff-child interactions (Carr \& Mitchel, 2009 and National Institute of Early Education Research, 2003).

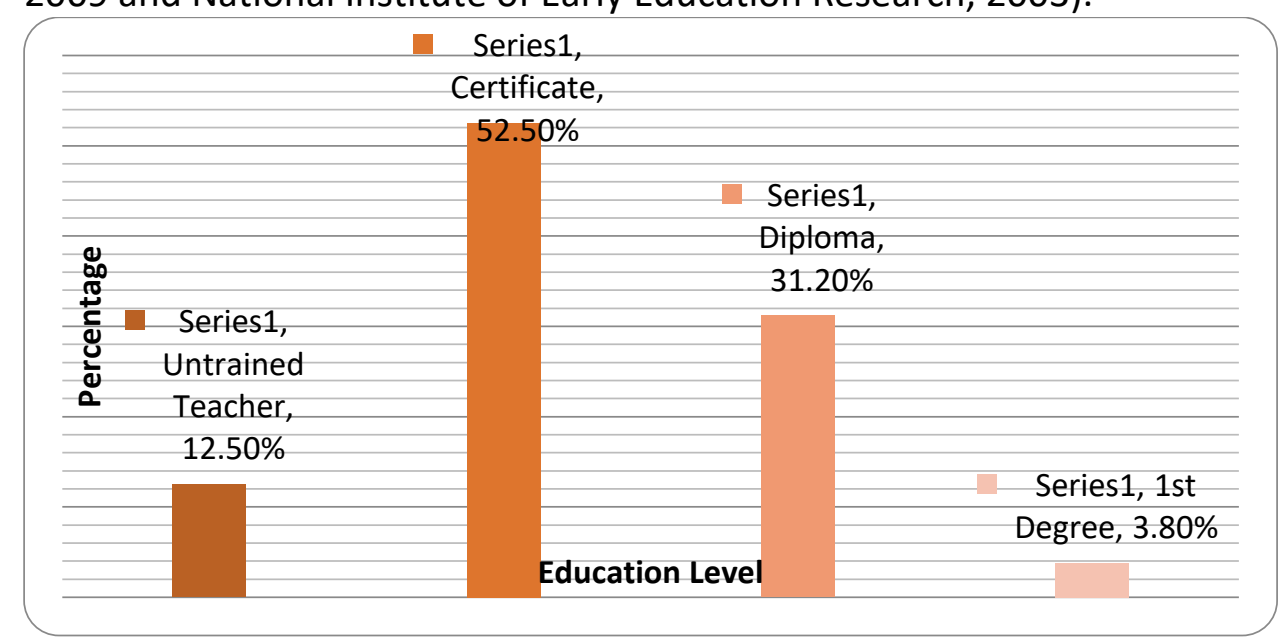

\section{Figure figure 4: Education Level of the Respondents}

\section{Work Experience}

The respondents were asked to indicate their work experience in the questionnaire as shown below.

Figure 4 shows that $42.5 \%$ teachers had $11-15$ years teaching experience, $32.5 \%$ teachers had $5-10$ years teaching experience, $11.2 \%$ teachers had a teaching experience of less than five years, $7.5 \%$ teachers had a teaching experience of over 20 years while on the other hand $6.2 \%$ teachers had a teaching experience of $15-20$ years. It emerged from the findings that majority of the teachers $56.2 \%$ had a teaching experience of more than 10 years implying that they are expected to be effective in their classrooms undertakings which should translate to increased learner engagement and achievement including the ability to read and write (Parents Across America, 2013). Further, Singal (2009) argued that that the credibility of the information gathered in any study is informed by the many years of the respondents' service to the organization. The experience proves the validity and reliability of the information obtained. Their skills, knowledge and expertise had been tested for a long period hence their perception on the matter under study had been influenced by their experience. 


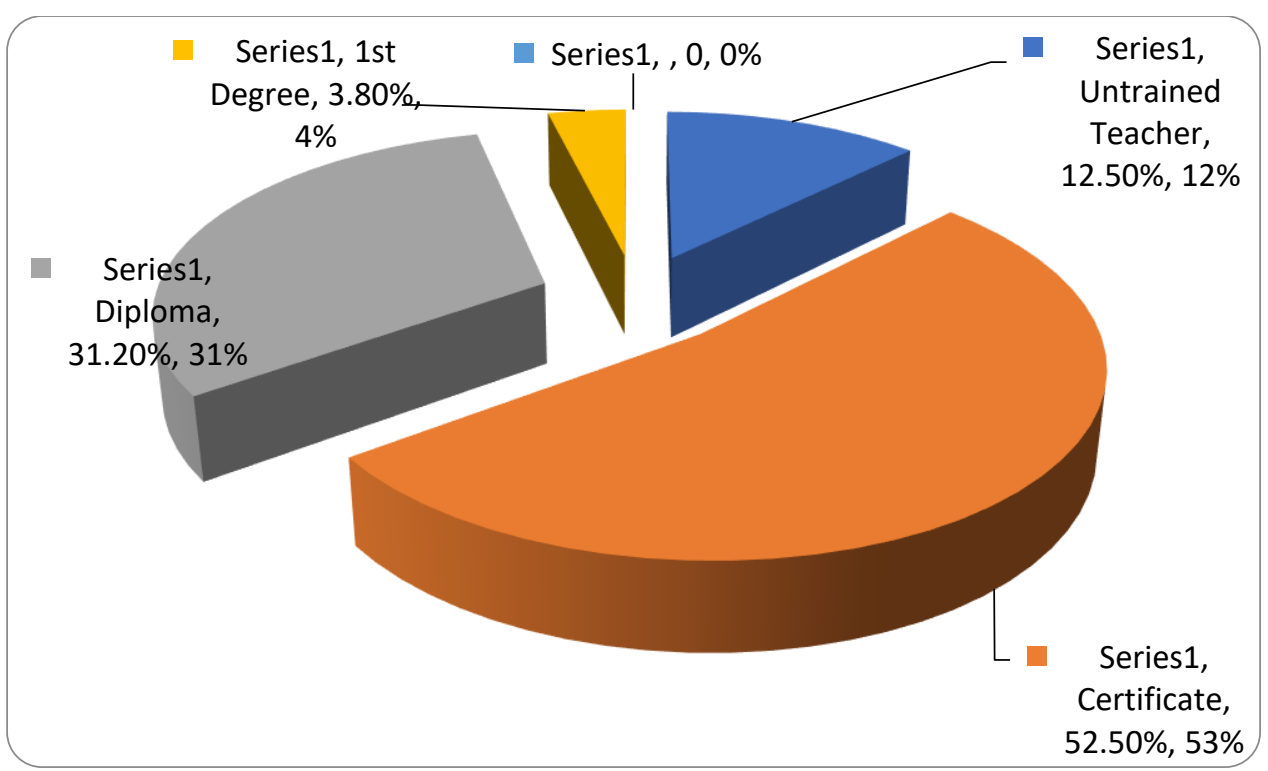

Figure 2: Teaching Experience of the respondents

Teachers Perception on the Influence of Teachers Experience on Pupils Ability to Read Write Teachers' experience plays a significant role in learners' achievements including the ability to read and write. The first objective of the study sought to determine teachers' perception on the influence of teachers experience on pupils' ability to read write in private pre- schools in Eldoret East sub county. The results of data analysis are presented in Table 5.

Table 5: Teachers perception on the influence of their experience on pupils ability to read and write

$\mathbf{N}=\mathbf{8 4}$

\begin{tabular}{llllll}
\hline Teachers' perception & SD & D & UD & A & SA \\
\cline { 2 - 7 } & $\%$ & $\%$ & $\%$ & $\%$ & $\%$ \\
\hline $\begin{array}{l}\text { Teachers who have taught pre-schools for a length of time } \\
\text { are more effective in assisting learners in pre-school to }\end{array}$ & 0.0 & 38.8 & 2.5 & 23.8 & 35.0 \\
read and write & & & & \\
$\begin{array}{l}\text { Teachers who are fresh from training are able to facilitate } \\
\text { learners to read and write in pre-school }\end{array}$ & 33.8 & 47.5 & 3.8 & 0.0 & 15.0 \\
$\begin{array}{l}\text { Teachers who have taught language for a length of time are } \\
\text { able to assist learners' to read and write successfully in pre- } \\
\text { schools }\end{array}$ & 10.0 & 0.0 & 0 & 70.0 & 20.0 \\
$\begin{array}{l}\text { Teachers who have never attended refresher courses are } \\
\text { able to facilitate learning in -pre-schools }\end{array}$ & 31.2 & 30.0 & 1.3 & 13.8 & 23.8 \\
$\begin{array}{l}\text { Teachers who have taught more than two pre-schools can } \\
\text { effectively instruct learners on reading and writing }\end{array}$ & 26.3 & 0.0 & 5.0 & 20.0 & 48.8 \\
$\begin{array}{l}\text { Teachers who have taught pre-schools in both rural and } \\
\text { urban setups have variety of skills in handing learners to }\end{array}$ & 7.5 & 20.0 & 2.5 & 31.2 & 38.8 \\
read and write & & & & & \\
$\begin{array}{l}\text { Teachers who have more experience do not perform well } \\
\text { with learners in under-privileged pre-schools in instructing } \\
\text { learners to read and write }\end{array}$ & 51.2 & 38.8 & 2.5 & 7.5 & 0.0 \\
\hline
\end{tabular}




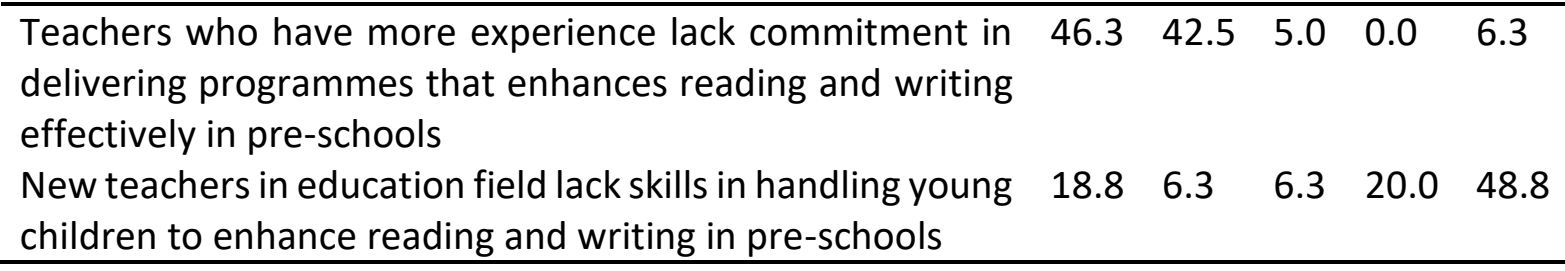

Source: Field Data, 2013

Table 5 shows that $58.8 \%$ agreed with the statement that teachers who have taught preschools for a length of time were more effective in assisting learners in pre-school to read and write, and $38.8 \%$ disagreed with the statement while $2.5 \%$ teachers were undecided on the statement. The study findings suggested that majority $(58.8 \%)$ of the public pre-school teachers in Eldoret East sub county were of the view that teachers' higher teaching experience makes one to be effective in service delivery enabling pre-scholars to be effective in reading and writing skills. This shows that teachers with higher teaching experience are more effective in teaching reading and writing skills an assertion which is supported by the America's Public Centre for Education (2005) which showed that level of teachers' experience correlates positively with student academic achievement and teachers with more than five years in the classroom were shown to be the most effective in classroom delivery. This implies that pre-school teachers with higher teaching experience were able to positively influence public pre-school pupils' ability to read and write translating to effective teaching.

Further, majority at $81.3 \%$ of pre-school teachers agreed with the statement that teachers who were fresh from training were able to facilitate learners to read and write in public preschools, and only $15.0 \%$ disagreed with the statement while $3.8 \%$ teachers were undecided with the statement. This implies that teachers with minimal experience were capable of effecting proper teaching towards reading and writing. Teaching experience is cited by several studies as having an influence on teacher's attitudes. The finding is supported by Dough and Lindsay (1991) who found that younger teachers and those with fewer years of experience had been found to be more supportive in new innovation and had a positive attitude towards their pupils. Further, according to Leyser et al., (1994), teachers with 14 years or less teaching experience had significantly higher positive score in their attitudes to innovation than those with more than 14 years. They found no significant differences in attitudes to integration among teachers whose teaching experience was between four, five and nine years and ten and 14 years. In a study by Roberts and Lind sell (1997), teachers who taught pupils in their classes were more positive in their attitudes than teachers with no experience of innovation. Teachers' attitudes appear to vary with their perceptions of the innovations according to teaching experience. The above studies regarding teaching experience indicated that younger teachers and those with fewer years of experience were more supportive to innovations and therefore influenced positively pupils' ability to read and write. In contrast, however, Forlin (2008) argued that the increasing implementation of national standards in many countries, large class sizes, lack of learning and teaching resources, lack of physical facilities and large teacher workload among other school based factors make a commitment to allow for proper reading and writing very difficult particularly if done by teachers soon out of training as they are not aware of the deep issues involved.

In addition, $90.0 \%$ of the public pre-school teachers' agreed with the statement that teachers who had taught language for a length of time were able to assist learners' ability to read and 
write successfully in pre-schools, while $10.0 \%$ pre-school teachers disagreed. The study findings showed that language teachers who had taught for quite some time positively influenced pupils' ability to read and write as they have higher experience in teaching of writing and reading skills. This implies that teachers with higher teaching experience especially in languages translate to higher pupils' achievement in reading and writing skills in public pre-schools. This is in agreement with literature which suggested the years of experience and particularly in teaching languages results in more positive changes in pupils' reading and writing skills (Avramidis \& Kalyva, 2007; Jung, 2007). However, Villa et al, (2006) reported that experience teaching languages is not one of the most influential factors in pupils' reading and writing skills as often purported because other disciplines can do the same.

Similarly, $61.2 \%$ pre-school teachers disagreed with the statement that teachers who had never attended refresher courses were able to facilitate learning in pre-schools, $37.6 \%$ preschool teachers on the other hand agreed with the statement while $1.3 \%$ pre-school teacher was undecided with the statement. It can therefore be argued that teachers who had never attended refresher courses were unable to facilitate learning in pre-schools therefore hindering learner's ability to read and write. This implies that in-service training is an important element for teachers to get new skills and techniques of handling pre-school learners and therefore be efficient in influencing positively learner's ability to read and write. These were echoed by Marchesi (1998) who reported that professional training of teachers was one of the key factors to successful teaching. Siegel and Jausovce (1994) further highlighted that in- service training was an effective way of improving teachers' attitude towards teaching. The study findings therefore suggests that pre-school teachers need to have regular in-service trainings to help them in acquiring new skills in handling pre-school children and at the same time as a way of motivation which in turn translates to better achievement for pre-school pupils.

Further, $68.8 \%$ teachers agreed with the statement that teachers who had taught more than two pre-schools can effectively instruct learners on reading and writing, while $26.3 \%$ teachers disagreed with the statement while $5.0 \%$ teachers were undecided with the statement. It can therefore be implied that pre-school teachers perceived that teachers who had taught in more than two pre-schools could effectively instruct learners on reading and writing due to their vast experience in several schools. Parasuram (2006) in agreement with this finding found that teachers reported the most positive perceptions toward their ability to effectively teach after 1 to 5 years experience and 25 or more years of experience. The positive attitudes of the more beginner group were attributed to an increased exposure to technology and changing attitudes while the more positive attitudes of the experienced group were due to their extensive classroom experience. However in disagreement with this finding, Avramidis \& Kalyva, (2007) noted that what they have found is that often competence to teach effectively was more innate and did not depend solely on the number of schools taught but on the quality of pre-service training received.

Notwithstanding, $70.0 \%$ of the teachers agreed that teachers who have taught pre-schools in both rural and urban setups have variety of skills in facilitating learners to read and write, $27.5 \%$ disagreed with the statement while $2.5 \%$ pre-school teachers were undecided with the statement. It can therefore be argued that teaching in both rural and urban setups enables 
teachers to gain skills in handling learners from different setups and therefore could positively influence leaner's ability in reading and writing skills. This implies that the more one is transferred to different schools, the more he/she gains experience on facilitating learners from various backgrounds to read and write. Larrivee and Cook (2009) after surveying 941 public institution teachers found that along with experience, a public school teacher perceived success in teaching pupils to read and write partly on the fact that they had handled the pupils at different public school contexts. The researchers asserted that experience teaching pupils' at different public schools contexts improve the public school teachers' confidence and instruction and thus their prowess in enabling proper reading and writing among their charges. In contrast, Singal (2009) and Forlin (2008) in a study of 453 and 657 teachers respectively found that the public schools contexts did not play a significant role in effective reading and writing of pupils, concluding that what was necessary was proper training, a positive attitude and adequate reading and writing resources.

On the statement that teachers who have more experience do not perform well with learners in under-privileged pre-schools in instructing learners to read and write, $90.0 \%$ of teachers disagreed with the statement, $7.5 \%$ teachers agreed with the statement while $2.5 \%$ preschool teachers were undecided on the statement. It seems therefore that teachers who had more experience could perform well with learners in under-privileged pre-schools in instructing them to read and write. This shows that experience makes teachers to have better skills and techniques of handling learners in all types of schools. This was shown to support Larrivee and Cook (2009) who noted that teachers, who have confidence in their ability to meet the educational needs of the learners, are more willing to try multiple instructional strategies to ensure student success and are more likely to persevere with difficult and underprivileged pupils rather than taking a custodial approach to their education. However, Brownell \& Pajares, (2009) argued that often experience breeds pride and contempt which creates a situation where teachers who have more experience do not perform well with learners in under-privileged pre-schools in instructing them to read and write.

When asked if teachers who have more experience lack commitment in delivering programmes that enhances reading and writing effectively in pre-schools, $88.8 \%$ pre-school teachers disagreed with the statement, $6.3 \%$ pre-school teachers agreed with the statement while $5.0 \%$ teachers were undecided on the statement. This implies that teachers with higher teaching experience have higher commitment in service delivery enhancing effective reading and writing skills development amongst the learners. This is agreed to by Larrivee and Cook (2009) who noted that experience leads to commitment. However, this is disagreed to by Kagan (2008) who noted that Pre-service teachers enter college education programs with firmly held attitudes or beliefs based on their own personal experiences as pupils and most graduate with the same belief system about teaching that they held before beginning their program and they carry that to schools with a show on non commitment that often continues even after a long teaching experience (Kagan, 2008). For some, their beliefs and biases become more deeply embedded during their pre-service experiences. Pajares (2006) asserted that the longer a belief is held, the more difficult it may be to change and as a result, no amount of experience can change someone's commitment to service delivery.

Lastly, $68.8 \%$ of the teachers agreed with the statement that new teachers in education field lacked skills in facilitating young children to enhance reading and writing in pre-schools, $25.1 \%$ 
teachers disagreed with the statement while $6.3 \%$ pre-school teachers were undecided with the statement. It seems therefore that majority (68.8\%) of the pre-school teachers believed that new teachers lacked skills in preparing pupils to read and write. This implies that new teachers in education field lacked skills in facilitating young children, inhibiting reading and writing skills in pre-schools. Jung (2007), when comparing the perception of pre-service teachers and student teachers on skills to effectively teach, found that pre-service teachers showed more positive attitudes but less skills to teach to read and write. Also in the same study, student teachers who had participated in quality field experiences working with pupils reported more positive attitudes and skills in teaching suggesting that the finding here is correct. But, Forlin (2008) noted in his study and findings that overall, new teachers in education field did not lack skills in facilitating young children to enhance reading and writing but simply needed more confidence.

Further, the cumulative Teachers' perception on the influence of their experience on pupils' ability to read and write

\section{Summary, Conclusions and Recommendations Summary of the Findings}

Teachers perception on the influence of teachers experience on pupils ability to read write The study findings suggested that majority (58.8\%) of the pre-school teachers in Eldoret East sub county were of the view that teachers' higher teaching experience makes one to be effective in service delivery enabling pre-scholars to be effective in reading and writing skills. This shows that teachers with higher teaching experience are more effective in teaching reading and writing skills an assertion which is supported by the America's Public Centre for Education (2005) which showed that level of teachers' experience correlates positively with student academic achievement and teachers with more than five years in the classroom were shown to be the most effective in classroom delivery. Further teachers with minimal experience were capable of effecting proper teaching towards reading and writing. Teaching experience is cited by several studies as having an influence on teacher's attitudes. In addition, $90.0 \%$ of the pre-school teachers agreed with the statement that teachers who had taught language for a length of time were able to assist learners' ability to read and write successfully in pre-schools. Teachers with higher teaching experience especially in languages translated to higher pupils' achievement in reading and writing skills in pre-schools (Avramidis \& Kalyva, 2007; Jung, 2007). Similarly, Teachers who had never attended refresher courses were unable to facilitate learning in pre-schools therefore hindering learner's ability to read and write. This implies that in-service training is an important element for teachers to get new skills and techniques of handling pre-school learners and therefore be efficient in influencing positively learner's ability to read and write. Further, $68.8 \%$ pre-school teachers perceived that teachers who had taught in more than two pre-schools could effectively instruct learners on reading and writing due to their vast experience in several schools. Parasuram (2006) in agreement with this finding found that teachers reported the most positive perceptions toward their ability to effectively teach after 1 to 5 years experience and 25 or more years of experience.

Teaching in both rural and urban setups enabled teachers to gain skills in handling learners from different setups and therefore could positively influence leaner's ability in reading and writing skills. This implies that the more one is transferred to different schools, the more he/she gains experience on facilitating learners from various backgrounds to read and write. 
Larrivee and Cook (2009) after surveying 941 public institution teachers found that along with experience, a public school teacher perceived success in teaching pupils to read and write partly on the fact that they had handled the pupils at different public schools contexts. The researchers asserted that experience teaching pupils at different public schools contexts improve the public school teachers' confidence and instruction and thus their prowess in enabling proper reading and writing among their charges. Furthermore teachers who had more experience could perform well with learners in under-privileged pre-schools in instructing them to read and write. This shows that experience makes teachers to have better skills and techniques of handling learners in all types of schools. Teachers with higher teaching experience have higher commitment in service delivery enhancing effective reading and writing skills development amongst the learners. This is agreed to by Larrivee and Cook (2009) who noted that experience leads to commitment. Lastly, majority (68.8\%) of the pre-school teachers believed that new teachers lacked skills in preparing pupils to read and write. This implies that new teachers in education field lacked skills in facilitating young children, inhibiting reading and writing skills in pre-schools. Jung (2007), when comparing the perception of pre-service teachers and student teachers on skills to effectively teach, found that pre-service teachers showed more positive attitudes but less skills to teach to read and write.

The study findings suggest that experience plays a significant role in determining pupils' ability to read and write in pre-schools. This shows that teachers with higher teaching experience are more effective in teaching reading and writing skills an assertion which is supported by the America's Public Centre for Education (2005) which showed that level of teachers' experience correlates positively with student academic achievement and teachers with more than five years in the classroom were shown to be the most effective in classroom delivery.

\section{Conclusions of the Study}

The study concluded that teachers experience plays a significant role in determining pupils' ability to read and write in pre-schools since teachers with higher teaching experience were shown to be more effective in teaching enabling learners to acquire reading and writing skills. Further it was shown that teachers who had never attended refresher courses were unable to facilitate learning in pre-schools therefore hindering learner's ability to read and write.

\section{Recommendations of the Study}

There is need for teachers to attend refresher courses to enable them to facilitate learning in pre-schools therefore enhancing learner's ability to acquire reading and writing skills.

\section{Reference}

Tella, A. (2013). Teacher variables as predictors of academic achievement of primary school pupils mathematics. International Electronic Journal of Elementary Education, 1(1), 1633.

ChacOn, C. T. (2005). Teachers' perceived efficacy among English as a foreign language teachers in middle schools in Venezuela. Teaching and Teacher Education, 21(3), 257272.

Hoffman, D. M. (2000). Pedagogies of self in American and Japanese early childhood education: A critical conceptual analysis. The Elementary School Journal, 101(2), 193208. 
Han, H. S. (2009). Sociocultural influence on children's social competence: A close look at kindergarten teachers' beliefs. Journal of research in childhood education, 24(1), 80-96.

Kenya Institute of Education. (2009). Guidelines for Early childhood Development in Kenya. Nairobi: NACECE

Kabiru, M., \& Njenga, A. (2007). General Psychology and personality; a study guide for Diploma in ECD: paper line Ltd Nairobi.

Tong, F. (2006). Oral English development and its impact on emergent reading achievement: A comparative study of transitional bilingual and structured English immersion models. Unpublished doctoral dissertation, Texas A\&M University, College Station, Texas.

Kabiru, M., Njengam, A., \& Swadener, B. B. (2003). Early childhood development in Kenya: Empowering young mothers, mobilizing a community. Childhood Education, 79(6), 358363.

Angrist, J. D., \& Lavy, V. (2001). "Does Teacher Training Affect Pupil Learning? Evidence from Matched Comparisons in Jerusalem Public Schools." Journal of Labor Economics 19(2): 343-369.

Card, D., \& Krueger, A. (1996). School resources and student outcomes: An overview of the literature and new evidence from North and South Carolina. Journal of Economic Perspectives, 10, 31-40.

Schleicher, A. (2012). Preparing Teachers and Developing School Leaders for the 21st Century: Lessons from around the World. OECD Publishing. 2, rue Andre Pascal, F-75775 Paris Cedex 16, France.

Hanushek, E. A., \& Luque, J. A. (2003). Efficiency and equity in schools around the world. Economics of Education Review, 22, 481-502 